\title{
Growth and Yield Response of Groundnut (Arachis hypogaea L.) Varieties to Plant Density
}

\author{
Gilbert Nwogboduhu Nwokwu \\ Department of Crop Production and Landscape Management, Ebonyi State University \\ Abakaliki, Nigeria. E-mail: g.nwokwu@yahoo.com
}

Ifeoma Lilian Agbedo Odoh

Department of Crop Production and Landscape Management, Ebonyi State University, Abakaliki, Nigeria. E-mail: lilianifeoma111@gmail.com

\begin{abstract}
Egwu Patricia Ngozi
Department of Agricultural Economics, Management and Extension, Ebonyi State University, Abakaliki. Nigeria. E-mail: triciaegwu@gmail.com
\end{abstract}

Received: Jan. 1, 2020

doi:10.5296/jas.v8i3.16976
Accepted: Apr. 12, $2020 \quad$ Published: May 6, 2020

URL: https://doi.org/10.5296/jas.v8i3.16976

\begin{abstract}
A field experiment was conducted at the research field of Faculty of Agriculture and Natural Resources Management, Ebonyi State University Abakaliki during the 2018 farming season to determine the effect of plant density on growth, yield and yield components of groundnut varieties. The experiment was conducted in a $3 \times 4$ factorial laid out in a randomized complete block design (RCBD). The treatments comprised three groundnut varieties (SAMNUT 24, 25 and 26) and four planting densities (40,000, 80,000, 120,000, and 160,000 plants ha ${ }^{-1}$ ). Each treatment was replicated four times. The parameters measured were plant height, number of leaves per plant, number of branches per plant, days to $50 \%$ flowering, shoot dry weight, leaf area index, crop growth rate, relative growth rate, net assimilation rate, number of pod per plant, pod weight per plant, hundred seed weight, number of seeds per plant, shelling percentage and total yield per hectare. The results showed that groundnut varieties were significant in all growth and yield parameters assessed except number of days to $50 \%$ flowering, Relative Growth Rate, number of pod per plant, and hundred seed weight while planting density recorded significant effect on all the growth and yield parameters. There were also significant interaction effects of varieties and plant density on plant height, number
\end{abstract}


of branches per plant, leaf area index, relative growth rate, pod weight per plant, number of seeds per plant, and total yield per hectare. This result indicated that SAMNUT 26 and plant density of 160,000 plants ha $^{-1}$ recorded the highest yield of groundnut and can be recommended for the farmers in the study area.

Keywords: groundnut, density, variety, growth, yield

\section{Introduction}

Groundnut (Arachis hypogaea L.) is a leguminous crop belonging to the family Fabaceae and is cultivated in the semi-arid and subtropical regions of the world. It is a self-pollinated, annual herbaceous plant growing 30 to $50 \mathrm{~cm}$ (1.0 to $1.6 \mathrm{ft}$.) tall. Groundnuts are known by many other local names such as peanut, earthnut, monkey nut, pygmy nut and pignut. Despite its name and appearance, groundnut is not a nut, but rather a species in the legume or "bean" family. Groundnuts are rich in essential nutrients which are potential to provide health benefits. (Janila and Mula, 2015).

The major groundnut producing countries in the world are India, China, Nigeria, Senegal, Sudan, Burma and the United States of America. Nigeria is the fourth largest producer in the world and the highest producer in Africa with 1.55 million metric tons accounting for $51 \%$ of production in the region. The country contributes $10 \%$ of total global production and $39 \%$ that of Africa (Ajeigbe et al 2014).

Cultivated groundnut has two subspecies, hypogaea and fastigiata, which in turn have two botanical varieties (var, hypogaea and var. aequatoriana). Each of these botanical varieties has different plant, pod and seed characteristics. However, most of the commercially cultivated varieties belong to the hypogaea (common name/market type: Virginia or runner), fastigiata (Valencia), and vulgaris (Spanish) botanical variety groups.

Plant density in a given area greatly influences growth and development of crops particularly the yield and yield components. In order to reduce low pod yield, pests and diseases infestation, competition for light, nutrients and water, determining optimum plant density for groundnut varieties is imperative to maximize productivity of the crop (Amato et al., 1992). Plant density is defined as the number of main stems within a unit area of land and crop yield is determined by the efficiency with which plant population uses available environmental resources for growth. Typical plant population densities on farmers' fields range from 8 to 10 plants $\mathrm{m}^{-2}$ compared with the recommended plant population density of 20 plants $\mathrm{m}^{-2}$ (Adu-Dapaah et al., 2004; Naab et al., 2005; Naab et al., 2009; FAO 2010). Most small-holder farmers either plant their groundnuts randomly on the flat land without any defined plant spacing or on mounds constructed haphazardly. In both practices, the plant spacing adopted are usually very wide. Planting groundnut in wide rows or spacing is reported to lead to sub-optimum plant population densities and lower yields (Tillman et al., 2006).

Few farmers plant the crop in well defined (spaced) rows or ridges, which when adopted tend to achieve optimum plant populations. Generally, altering plant population densities can affect crop growth and development, yield, quality factors and pest development in groundnut 
(Lanier et al., 2004; Mlingo et al., 2007). Attaining optimum plant population densities, particularly when close or narrow row spacing are adopted, can lead to early and complete canopy closure, greater LAI, increased solar radiation interception and utilization, reduced weed/crop competition, reduced incidence and severity of some diseases (e.g. groundnut rosette virus), increased crop growth rates and yields (Lanier et al., 2004; Dalley et al., 2004). Therefore, the objective of this study was to determine the optimum plant population density on the growth and yield of the groundnut varieties in the study area.

\section{Materials and Methods}

The field experiment was carried out during the 2018 rainy season at the experimental field of the Faculty of Agriculture and Natural Resources Management, Ebonyi State University Abakaliki. Abakaliki is located approximately on latitudes $6^{0} 04^{\prime} \mathrm{N}$, and longitudes $8^{0} 05^{\prime} \mathrm{E}$, at an elevation of $94 \mathrm{~m}$ above sea level. It is in the derived savannah zone of southern Nigeria. The climate is characterized by daily temperature ranging from 22 to $32^{\circ} \mathrm{C}$. It experiences bimodal pattern of rainfall (April to July and September to November) with short spell in August called "August break". Total annual rainfall ranges between $1500-2000 \mathrm{~mm}$, with a mean of $1,800 \mathrm{~mm}$ and in form of intensive violent showers of short duration. The relative humidity is $80 \%$ during rainy season and declines to $65 \%$ in dry season (EBADEP, 2005). The experiment was laid out in a randomized complete block design (RCBD) in $3 \times 4$ factorial arrangements with three varieties of groundnut (Samnut 24, 25 and 26) as factor A and four planting densities $\left(40,000,80,000,120,000\right.$ and 160,000 plants ha $^{-1}$ ) as factor B. The treatments used which gave a total of 12 treatment combinations were replicated four times and each replication (block) consisting of twelve plots making a total of 48 plots. Each plot was measured $2 \mathrm{~m} \times 2 \mathrm{~m}\left(4 \mathrm{~m}^{2}\right)$ with $0.5 \mathrm{~m}$ between adjacent plot and $1.0 \mathrm{~m}$ between replicates. The area size was $12 \mathrm{~m} \times 30 \mathrm{~m}$ for the width and length respectively, which gave a total area of $360 \mathrm{~m}^{2}$. The three groundnut varieties (Samnut 24, 25 and 26) were sourced from Institute for Agriculture Research, Ahmadu Bello University Zaria, Nigeria. The total area was tilled and leveled manually with hoe to obtain fine tilled area and the area was divided into four blocks and then into $2 \mathrm{~m} \times 2 \mathrm{~m}$ plots as per the treatments. The seeds were sown directly into the field at two seeds per hole; at a depth of $5 \mathrm{~cm}$ and spacing depended on the variety and the plant density in each plot. Weed was controlled manually by hand pulling at least two to three times before maturity. Harvesting was done when the matured groundnut leaves turned brown in color. The net plots were harvested by digging out the whole plant with a hoe. Thereafter, the pods were picked from the main bunch and sun dried for few days. Data were collected from four randomly tagged plants in each plot on growth and yield parameters. The statistical analysis of data was based on the procedure for a randomized complete block design (RCBD) for factorial experiment as outlined by Steel and Torrie (1980) and separation of treatment means for significant effect was by the use of F-LSD as described by Obi (1986).

\section{Results}

Results presented in (Table 1) indicated that variety, plant density and their interaction had significant effect $(\mathrm{P}<0.05)$ on plant height. The result showed that SAMNUT 26 significantly 
produced the tallest plants $(75.75 \mathrm{~cm})$ followed by SAMNUT 25 which recorded $(73.84 \mathrm{~cm})$ while SAMNUT 24 produced the shortest plants $(70.82 \mathrm{~cm})$. With regards to plant density, 160,000 plants/ha significantly recorded the tallest plants $(85.04 \mathrm{~cm})$ followed by 120,000 plants/ha $(75.87 \mathrm{~cm})$ while the shortest plants produced $(62.44 \mathrm{~cm})$ were recorded by 40,000 plants/ha. The interaction of SAMNUT 26 and 160,000 plants/ha produced the tallest plants $(84.23 \mathrm{~cm})$ while the shortest plants were recorded by SAMNUT 24 and 40,000 plants/ha $(60.18 \mathrm{~cm})$.

Variety and plant density had significant effect $(\mathrm{P}<0.05)$ on the number of leaves from the result presented in (Table 2). The highest number of leaves per plant (197.79) was recorded from the variety 'SAMNUT 26' followed by SAMNUT 25 (190.06) while the lowest (141.38) was recorded for the variety 'SAMNUT 24' which is a bunch type in its growth habit. With regards to plant density, the highest number of leaves per plant (200.92) was recorded from the lowest plant density (40,000 plants/ha) followed by plant density of 80,000 plants/ha (180.58) while the lowest number of leaves (157.13) was recorded from the highest plant density $(160,000$ plants/ha). There was no significant difference $(\mathrm{P}>0.05)$ among the treatment combinations tried. The highest number of leaves (220.75) was observed with groundnut variety, SAMNUT 26 at plant density of 40,000 plants/ha while the lowest number of leaves (116.00) was registered with SAMNUT 24 at plant density of 160,000 plants/ha.

Results presented in (Table 3) indicated that variety, plant density and their interaction had significant effect $(\mathrm{P}<0.05)$ on number of branches. SAMNUT 26 significantly produced the highest number of branches (9.19) followed by SAMNUT 24 (9.06) while SAMNUT 25 produced the lowest number of branches (8.96). Plant density of 40,000 plants/ha significantly recorded the highest number of branches (9.92) followed by 80,000 plants/ha (9.25) while the lowest number of branches (8.00) were recorded by 160,000 plants/ha. The interaction of SAMNUT 26 and 40,000 plants/ha produced the highest number of branches (10.25) while the lowest number of branches were recorded by SAMNUT 25 and 160,000 plants/ha (7.75).

There was no significant difference $(\mathrm{P}>0.05)$ among the variety studied on days to $50 \%$ flowering (Table 4). 'SAMNUT 24' was the first to reach its 50\% flowering at (25.00) while variety "SAMNUT 25 and 26" flowered late. Plant density showed significance $(\mathrm{P}<0.05)$ on days to $50 \%$ flowering. The result revealed that the crops flowered earlier at higher planting densities 160,000 and 120,000 plants/ha) and flowered late (27.33) at lower plant density (40,000 plants/ha). The interaction between Varieties and plant densities had no significant difference $(\mathrm{P}>0.05)$. 'SAMNUT 24' planted at planting density of 160,000 plants/ha was the first to reach its $50 \%$ flowering at (23.75) while variety 'SAMNUT 26' planted at the density of 40,000 plants/ha flowered late (27.75).

Variety and plant density had significant effect $(\mathrm{P}<0.05)$ on the Shoot Dry Weight from the result presented in (Table 5). The heaviest Shoot Dry Weight (17.67 g) was recorded from the variety 'SAMNUT 25'while the lowest (14.14 g) was recorded for the variety 'SAMNUT 26'. With regards to plant density, the heaviest Shoot Dry Weight $(28.21 \mathrm{~g})$ was recorded from the lowest plant density (40,000 plants/ha) while the lowest Shoot Dry Weight (5.66 g) was 
recorded from the highest plant density $(160,000$ plants/ha).There was no significant difference $(\mathrm{P}>0.05)$ among the treatment combinations tried. The heaviest Shoot Dry Weight (32.97 g) was observed with groundnut variety, SAMNUT 24 at plant density of 40,000 plants/ha while the lowest Shoot Dry Weight (5.46 g) was registered with SAMNUT 24 at plant density of 160,000 plants/ha.

Table 1. Effect of groundnut varieties, plant densities and groundnut varieties $\mathrm{x}$ plant densities on Plant Height $(\mathrm{cm})$

\begin{tabular}{lccccc}
\hline Groundnut & \multicolumn{5}{c}{ Plant densities (Plants/ha) } \\
Varieties & 40,000 & 80,000 & 120,000 & 160,000 & Mean \\
\hline Samnut 24 & 60.18 & 67.05 & 72.75 & 83.25 & 70.82 \\
Samnut 25 & 61.75 & 72.80 & 76.58 & 84.23 & 73.84 \\
Samnut 26 & 65.40 & 71.68 & 78.28 & 87.65 & 75.75 \\
\hline Mean & 62.44 & 70.51 & 75.87 & 85.04 &
\end{tabular}

F-LSD $(\mathrm{P}<0.05):$ Variety $=1.8$, Plant density $=2.12$, Interaction $=1.06$

Table 2. Effect of groundnut varieties, plant densities and groundnut varieties x plant densities on Number of Leaves

\begin{tabular}{lcrrrc}
\hline Groundnut & \multicolumn{5}{c}{ Plant densities (Plants/ha) } \\
Varieties & 40,000 & 80,000 & 120,000 & 160,000 & Mean \\
\hline Samnut 24 & 169.50 & 149.00 & 131.00 & 116.00 & 141.38 \\
Samnut 25 & 212.50 & 193.25 & 180.25 & 174.25 & 190.06 \\
Samnut 26 & 220.75 & 199.50 & 189.75 & 181.15 & 197.79 \\
\hline Mean & 200.92 & 180.58 & 167.00 & 157.13 & \\
\hline
\end{tabular}

F-LSD $(\mathrm{P}<0.05)$ : Variety $=6.37$, Plant density $=7.35$, Interaction $=$ n.s

Table 3. Effect of groundnut varieties, plant densities and groundnut varieties $\mathrm{x}$ plant densities on Number of Branches

\begin{tabular}{lcclll}
\hline Groundnut & \multicolumn{5}{c}{ Plant densities (Plants/ha) } \\
Varieties & 40,000 & 80,000 & 120,000 & 160,000 & Mean \\
\hline Samnut 24 & 9.75 & 9.50 & 9.00 & 8.00 & 9.06 \\
Samnut 25 & 9.75 & 8.75 & 8.50 & 7.75 & 8.96 \\
Samnut 26 & 10.25 & 9.50 & 8.75 & 8.25 & 9.19 \\
\hline Mean & 9.92 & 9.25 & 8.75 & 8.00 & \\
\hline
\end{tabular}

F-LSD $(\mathrm{P}<0.05)$ : Variety $=0.12$, Plant density $=0.14$, Interaction $=0.08$ 
Table 4. Effect of groundnut varieties, plant densities and groundnut varieties $\mathrm{x}$ plant densities on Days to $50 \%$ flowering

\begin{tabular}{lcrrrr}
\hline Groundnut & \multicolumn{5}{c}{ Plant densities (Plants/ha) } \\
Varieties & 40,000 & 80,000 & 120,000 & 160,000 & Mean \\
\hline Samnut 24 & 27.00 & 25.00 & 24.25 & 23.75 & 25.00 \\
Samnut 25 & 27.25 & 26.00 & 25.25 & 24.50 & 25.75 \\
Samnut 26 & 27.75 & 25.75 & 25.00 & 24.25 & 25.69 \\
\hline Mean & 27.33 & 25.58 & 24.83 & 24.17 & \\
\hline \hline
\end{tabular}

F-LSD $(\mathrm{P}<0.05)$ : Variety $=$ n.s, Plant density $=1.88$, Interaction $=$ n.s

Table 5. Effect of groundnut varieties, plant densities and groundnut varieties $\mathrm{x}$ plant densities on Shoot Dry Weight (g)

\begin{tabular}{lccccc}
\hline Groundnut & \multicolumn{4}{c}{ Plant densities (Plants/ha) } \\
Varieties & 40,000 & 80,000 & 120,000 & 160,000 & Mean \\
\hline Samnut 24 & 29.08 & 20.15 & 9.85 & 5.46 & 16.14 \\
Samnut 25 & 32.97 & 21.50 & 10.22 & 5.99 & 19.67 \\
Samnut 26 & 22.58 & 19.78 & 9.86 & 5.33 & 14.14 \\
\hline Mean & 28.21 & 20.48 & 9.98 & 5.66 & \\
\hline
\end{tabular}

F-LSD $(\mathrm{P}<0.05)$ : Variety $=1.02$, Plant density $=1.18$, Interaction $=$ n.s

Results presented in (Table 6) indicated that variety, plant density and their interaction had significant effect $(\mathrm{P}<0.01)$ on leaf area index. SAMNUT 26 significantly produced the highest leaf area index (4.91) followed by SAMNUT 24 (4.78) while SAMNUT 25 produced the lowest leaf area index (4.25). Plant density of 160,000 plants/ha significantly recorded the highest leaf area index (6.19) followed by 120,000 plants/ha (5.20) while the lowest leaf area index (2.78) were recorded by 40,000 plants/ha. The interaction of SAMNUT 24 and 160,000 plants/ha produced the highest leaf area index (6.82) while the lowest leaf area index were recorded by SAMNUT 25 and 40,000 plants/ha (2.33).

Variety and plant density had significant effect $(\mathrm{P}<0.05)$ on crop growth rate from the result presented in (Table 7). The highest crop growth rate (4.42) was recorded from variety 'SAMNUT 25' followed by SAMNUT 26 (4.06) while the lowest (4.04) was recorded for the variety 'SAMNUT 24'. With regards to plant density, the highest crop growth rate (7.63) was recorded from the lowest plant density $(40,000$ plants/ha) while the lowest crop growth rate (1.42) was recorded from the highest plant density (160,000 plants/ha). There was no significant difference $(\mathrm{P}>0.05)$ among the treatment combinations tried. The highest crop growth rate (8.24) was observed with groundnut variety, SAMNUT 25 at plant density of 40,000 plants/ha. The lowest crop growth rate (1.37) was registered with SAMNUT 24 at 
plant density of 160,000 plants/ha.

Results presented in (Table 8) indicated that variety had no significant effect $(\mathrm{P}>0.05)$ on relative growth rate. SAMNUT 25 produced the highest relative growth rate $(0.37)$ followed by SAMNUT 25 and 24 which were at par (0.29). Plant density showed significant difference $(\mathrm{P}<0.05)$ on relative growth rate. Plant density of 40,000 plants/ha significantly recorded the highest relative growth rate $(0.37)$ followed by 80,000 plants/ha $(0.33)$ while the lowest relative growth rate (0.19) was recorded by 160,000 plants/ha. The interaction between varieties and plant density showed significant difference $(\mathrm{P}<0.05)$ on relative growth rate. SAMNUT 25 at 40,000 plants/ha produced the highest relative growth rate $(0.38)$ while the lowest relative growth rate was recorded by the three varieties at 160,000 plants/ha (0.19).

Variety and plant density had significant effect $(\mathrm{P}<0.05)$ on the net assimilation rate from the result presented in (Table 9). The highest net assimilation rate (1.53) was recorded from the variety 'SAMNUT 25' followed by SAMNUT 24 (1.39) while the lowest (1.37) was recorded for the variety 'SAMNUT 26 . With regards to plant density, the highest net assimilation rate (2.48) was recorded from the lowest plant density (40,000 plants/ha) followed by plant density of 80,000 plants/ha (1.72) while the lowest net assimilation rate (0.42) was recorded from the highest plant density (160,000 plants/ha). There was no significant difference $(\mathrm{P}>0.05)$ among the treatment combinations tried. The highest net assimilation rate (2.98) was observed with groundnut variety, SAMNUT 25 at plant density of 40,000 plants/ha while the lowest net assimilation rate (0.39) was registered with SAMNUT 24 at plant density of 160,000 plants/ha.

There was no significant difference $(\mathrm{P}>0.05)$ among the variety studied on the number of pods plant ${ }^{-1}$ (Table 10). The highest number of pods plant ${ }^{-1}$ (22.56) was recorded from variety 'SAMNUT 26' followed by SAMNUT 24 (22.25) while the lowest (21.44) was recorded for the variety 'SAMNUT 25' (Table 10). Plant density showed significance difference $(\mathrm{P}<0.05)$ on the number of pods plant ${ }^{-1}$. The highest number of pods plant ${ }^{-1}$ (29.25) was recorded from the lowest plant density (40,000 plants/ha followed by 80,000 plants/ha (25.75) whiles the lowest number of pods plant ${ }^{-1}$ (13.58) was recorded from the highest plant density $(160,000$ plants/ha). The interaction between Varieties and plant densities had no significant difference $(\mathrm{P}>0.05)$ on the Number of Pods Plant ${ }^{-1}$. Among the treatment combinations tried, the highest number of pods plant ${ }^{-1}$ (30.00) was observed with groundnut variety, SAMNUT 24 at plant density of 40,000 plants/ha while the lowest number of pods plant ${ }^{-1}$ (12.25) was registered with SAMNUT 25 at plant density of 160,000 plants/ha. 


\section{Mll Macrothink}

Table 6. Effect of groundnut varieties, plant densities and groundnut varieties x plant densities on Leaf area index

\begin{tabular}{lccccc}
\hline Groundnut & \multicolumn{5}{c}{ Plant densities (Plants/ha) } \\
Varieties & 40,000 & 80,000 & 120,000 & 160,000 & Mean \\
\hline Samnut 24 & 2.77 & 4.34 & 5.19 & 6.82 & 4.78 \\
Samnut 25 & 2.33 & 4.24 & 4.91 & 5.51 & 4.25 \\
Samnut 26 & 3.25 & 4.64 & 5.51 & 6.23 & 4.91 \\
\hline Mean & 2.78 & 4.41 & 75.87 & 85.04 & \\
\hline
\end{tabular}

F-LSD $(\mathrm{P}<0.05):$ Variety $=0.10$, Plant density $=0.12$, Interaction $=0.06$

Table 7. Effect of groundnut varieties, plant densities and groundnut varieties $\mathrm{x}$ plant densities on Crop growth rate

\begin{tabular}{lccccc}
\hline Groundnut & \multicolumn{5}{c}{ Plant densities (Plants/ha) } \\
Varieties & 40,000 & 80,000 & 120,000 & 160,000 & Mean \\
\hline Samnut 24 & 7.27 & 5.04 & 2.46 & 1.37 & 4.04 \\
Samnut 25 & 8.24 & 5.38 & 2.57 & 1.50 & 4.42 \\
Samnut 26 & 7.39 & 4.95 & 2.49 & 1.39 & 4.06 \\
\hline Mean & 7.63 & 5.12 & 2.51 & 1.42 & \\
\hline
\end{tabular}

F-LSD $(\mathrm{P}<0.05)$ : Variety $=0.29$, Plant density $=0.29$, Interaction $=$ n.s

Table 8. Effect of groundnut varieties, plant densities and groundnut varieties $\mathrm{x}$ plant densities on Relative Growth Rate

\begin{tabular}{llllll}
\hline Groundnut & \multicolumn{5}{c}{ Plant densities (Plants/ha) } \\
\cline { 2 - 5 } Varieties & 40,000 & 80,000 & 120,000 & 160,000 & Mean \\
\hline Samnut 24 & 0.37 & 0.33 & 0.25 & 0.19 & 0.29 \\
Samnut 25 & 0.38 & 0.34 & 0.27 & 0.19 & 0.30 \\
Samnut 26 & 0.37 & 0.33 & 0.25 & 0.19 & 0.29 \\
\hline Mean & 0.37 & 0.33 & 0.26 & 0.19 & \\
\hline
\end{tabular}

F-LSD $(\mathrm{P}<0.05)$ : Variety $=$ n.s, Plant density $=0.01$, Interaction $=6.72$ 
Table 9. Effect of groundnut varieties, plant densities and groundnut varieties $\mathrm{x}$ plant densities on Net Assimilation Rate

\begin{tabular}{lccccc}
\hline Groundnut & \multicolumn{5}{c}{ Plant densities (Plants/ha) } \\
Varieties & 40,000 & 80,000 & 120,000 & 160,000 & Mean \\
\hline Samnut 24 & 2.67 & 1.70 & 0.78 & 0.39 & 1.39 \\
Samnut 25 & 2.98 & 1.83 & 0.83 & 0.46 & 1.53 \\
Samnut 26 & 2.68 & 1.63 & 0.77 & 0.41 & 1.37 \\
\hline Mean & 2.78 & 1.72 & 0.79 & 0.42 & \\
\hline
\end{tabular}

F-LSD $(\mathrm{P}<0.05)$ : Variety $=0.10$, Plant density $=0.20$, Interaction $=$ n.s

Table 10. Effect of groundnut varieties, plant densities and groundnut varieties $\mathrm{x}$ plant densities on Number of Pods Plant ${ }^{-1}$

\begin{tabular}{lccccc}
\hline Groundnut & \multicolumn{5}{c}{ Plant densities (Plants/ha) } \\
Varieties & 40,000 & 80,000 & 120,000 & 160,000 & Mean \\
\hline Samnut 24 & 30.00 & 26.25 & 18.00 & 14.75 & 22.25 \\
Samnut 25 & 28.75 & 24.00 & 20.75 & 12.25 & 21.44 \\
Samnut 26 & 29.00 & 27.00 & 20.50 & 13.75 & 22.56 \\
\hline Mean & 29.25 & 25.75 & 19.75 & 13.58 & \\
\hline F-L SD (P<0.05): Variety $=$
\end{tabular}

F-LSD $(\mathrm{P}<0.05)$ : Variety $=$ n.s, Plant density $=1.49$, Interaction $=0.06$

Results presented in (Table 11) indicated that variety, plant density and their interaction had significant effect $(\mathrm{P}<0.01)$ on Pod Weight per Plant. SAMNUT 25 significantly produced the highest Pod Weight per Plant (26.17 g) followed by SAMNUT 26 (26.15 g) while SAMNUT 24 produced the lowest Pod Weight per Plant (23.03 g). Plant density of 40,000 plants/ha significantly recorded the heaviest Pod Weight per Plant (34.28 g) followed by 80,000 plants/ha (29.82 g) while the lowest Pod Weight per Plant (15.57 g) was recorded by 160,000 plants/ha. The interaction of SAMNUT 24 and 40,000 plants/ha produced the heaviest Pod Weight per Plant (35.52 g) while the lowest Pod Weight per Plant were recorded by SAMNUT 24 and 160,000 plants/ha (12.43 g).

There was no significant difference $(\mathrm{P}>0.05)$ among the variety studied on the hundred seed weight (Table 12). The heaviest Hundred Seed Weight (15.54 g) was recorded from variety 'SAMNUT 26' followed by SAMNUT 25 (14.70 g) while the lowest (14.33 g) was recorded for the variety 'SAMNUT 24'. Plant density showed significance difference $(\mathrm{P}<0.05)$ on the hundred seed weight. The heaviest hundred seed weight $(20.82 \mathrm{~g})$ was recorded from the lowest plant density (40,000 plants/ha followed by 80,000 plants/ha $(17.11 \mathrm{~g})$ whiles the lowest hundred seed weight $(9.17 \mathrm{~g})$ was recorded from the highest plant density $(160,000$ plants/ha). The interaction between Varieties and plant densities had no significant difference 
$(\mathrm{P}>0.05)$ on the hundred seed weight. Among the treatment combinations tried, the heaviest hundred seed weight (21.06 g) was observed with groundnut variety, SAMNUT 25 at plant density of 40,000 plants/ha while the lowest hundred seed weight ( $7.55 \mathrm{~g})$ was registered with SAMNUT 24 at plant density of 160,000 plants/ha.

Results presented in (Table 13) indicated that variety had no significant effect $(\mathrm{P}>0.05)$ on number of seeds per plant. SAMNUT 26 produced the highest number of seeds per plant (37.94) followed by SAMNUT 24 (37.56) while the lowest was recorded from SAMNUT 25 (35.11). Plant density showed significant difference $(\mathrm{P}<0.05)$ on number of seeds per plant. Plant density of 40,000 plants/ha significantly recorded the highest number of seeds per plant (50.67) followed by 80,000 plants/ha (43.57) while the lowest number of seeds per plant (21.67) was recorded by 160,000 plants/ha. The interaction between varieties and plant density showed significant difference $(\mathrm{P}<0.05)$ on number of seeds per plant. SAMNUT 24 at 40,000 plants/ha produced the highest number of seeds per plant (52.25) while the lowest number of seeds per plant was recorded by SAMNUT 25 at 160,000 plants/ha (19.00).

Variety and plant density had significant effect $(\mathrm{P}<0.05)$ on the Shelling Percentage from the result presented in (Table 14). The highest Shelling Percentage $(62.46 \%)$ was recorded from the variety 'SAMNUT 24' followed by SAMNUT 25 (60.76 \%) while the lowest (59.80 \%) was recorded for the variety 'SAMNUT 26. With regards to plant density, the highest Shelling Percentage $(62.00 \%)$ was recorded from the lowest plant density $(40,000$ plants/ha) followed by plant density of 80,000 plants/ha $(61.50 \%)$ while the lowest Shelling Percentage $(59.85 \%)$ was recorded from the highest plant density (160,000 plants/ha). There was no significant difference $(\mathrm{P}>0.05)$ among the treatment combinations tried. The highest Shelling Percentage $(63.31 \%)$ was observed with groundnut variety, SAMNUT 24 at plant density of 40,000 plants/ha while the lowest Shelling Percentage $(58.72 \%)$ was registered with SAMNUT 26 at plant density of 160,000 plants/ha.

The analysis of variance revealed that, variety, plant density and their interaction had significant effect $(\mathrm{P}<0.05)$ on total yield (Table 15). Among the varieties, the highest total yield $(5294.25 \mathrm{Kg} / \mathrm{ha}$ ) was obtained for the variety 'SAMNUT 26' followed by SAMNUT 25 $(5246.69 \mathrm{Kg} / \mathrm{ha})$ while the lowest total yield $(4701.19 \mathrm{Kg} / \mathrm{ha})$ was obtained for variety 'SAMNUT 24'. With regards to plant density, the highest total yield $(6775.17 \mathrm{Kg} / \mathrm{ha})$ was recorded from the highest plant density (160,000 plants/ha), followed by 120,000 plants/ha $(6114.58 \mathrm{Kg} / \mathrm{ha})$ while the lowest total yield $(3184.67 \mathrm{Kg} / \mathrm{ha})$ was recorded from the lowest plant density (40,000 plants/ha). The variety 'SAMNUT 25' at plant density of 160,000 plants/ha gave the highest total yield $(6826 \mathrm{Kg} / \mathrm{ha})$ while variety 'SAMNUT 24' at plant density of 40,000 plants/ha gave the lowest total yield $(2678.25 \mathrm{Kg} / \mathrm{ha})$. 
Table 11. Effect of groundnut varieties, plant densities and groundnut varieties $\mathrm{x}$ plant densities on Pod Weight per Plant (g)

\begin{tabular}{lccccc}
\hline Groundnut & \multicolumn{5}{c}{ Plant densities (Plants/ha) } \\
Varieties & 40,000 & 80,000 & 120,000 & 160,000 & Mean \\
\hline Samnut 24 & 35.52 & 28.57 & 17.61 & 12.43 & 23.03 \\
Samnut 25 & 35.49 & 29.62 & 22.09 & 17.49 & 26.17 \\
Samnut 26 & 33.84 & 31.27 & 22.72 & 16.78 & 26.15 \\
\hline Mean & 34.28 & 29.82 & 20.81 & 15.57 & \\
\hline
\end{tabular}

F-LSD $(\mathrm{P}<0.05)$ : Variety $=1.10$, Plant density $=1.27$, Interaction $=0.65$

Table 12. Effect of groundnut varieties, plant densities and groundnut varieties $\mathrm{x}$ plant densities on Hundred Seed Weight (g)

\begin{tabular}{lccccc} 
Groundnut & \multicolumn{5}{c}{ Plant densities (Plants/ha) } \\
Varieties & 40,000 & 80,000 & 120,000 & 160,000 & Mean \\
\hline Samnut 24 & 20.81 & 17.98 & 10.99 & 7.55 & 14.33 \\
Samnut 25 & 21.06 & 14.87 & 12.84 & 10.04 & 14.70 \\
Samnut 26 & 20.58 & 18.48 & 13.17 & 9.92 & 15.54 \\
\hline Mean & 20.82 & 17.11 & 12.33 & 9.17 &
\end{tabular}

F-LSD $(\mathrm{P}<0.05)$ : Variety $=$ n.s, Plant density $=2.74$, Interaction $=$ n.s

Table 13. Effect of groundnut varieties, plant densities and groundnut varieties $\mathrm{x}$ plant densities on Number of seeds per plant

\begin{tabular}{lccccc} 
Groundnut & \multicolumn{5}{l}{ Plant densities (Plants/ha) } \\
\cline { 3 - 5 } Varieties & 40,000 & 80,000 & 120,000 & 160,000 & Mean \\
\hline Samnut 24 & 52.25 & 46.75 & 28.50 & 22.75 & 37.56 \\
Samnut 25 & 50.25 & 37.95 & 33.25 & 19.00 & 35.11 \\
Samnut 26 & 49.50 & 46.00 & 33.00 & 23.25 & 37.94 \\
\hline Mean & 50.67 & 43.57 & 24.83 & 21.67 & \\
\hline
\end{tabular}

F-LSD $(\mathrm{P}<0.05):$ Variety $=$ n.s, Plant density $=2.88$, Interaction $=1.45$ 
Table 14. Effect of groundnut varieties, plant densities and groundnut varieties $\mathrm{x}$ plant densities on Shelling Percentage

\begin{tabular}{lccccc}
\hline Groundnut & \multicolumn{5}{c}{ Plant densities (Plants/ha) } \\
\cline { 3 - 5 } Varieties & 40,000 & 80,000 & 120,000 & 160,000 & Mean \\
\hline Samnut 24 & 63.31 & 63.10 & 62.12 & 61.30 & 62.46 \\
Samnut 25 & 61.81 & 61.37 & 60.33 & 59.53 & 60.76 \\
Samnut 26 & 60.89 & 60.02 & 59.55 & 58.72 & 59.80 \\
\hline Mean & 62.00 & 61.50 & 60.67 & 59.85 & \\
\hline
\end{tabular}

F-LSD $(\mathrm{P}<0.05):$ Variety $=0.35$, Plant density $=0.41$, Interaction $=$ n.s

Table 15. ffect of groundnut varieties, plant densities and groundnut varieties x plant densities on Total yield $(\mathrm{Kg} / \mathrm{ha})$

\begin{tabular}{lcrrrr} 
Groundnut & \multicolumn{5}{c}{ Plant densities (Plants/ha) } \\
Varieties & 40,000 & 80,000 & 120,000 & 160,000 & Mean \\
\hline Samnut 24 & 2678.25 & 3107.75 & 6271.50 & 6747.25 & 4701.19 \\
Samnut 25 & 3399.75 & 4863.00 & 5898.00 & 6826.00 & 5246.69 \\
Samnut 26 & 3476.00 & 4774.50 & 6174.25 & 6752.25 & 5294.24 \\
\hline Mean & 3184.67 & 4284.42 & 6114.58 & 6775.17 & \\
\hline
\end{tabular}

F-LSD $(\mathrm{P}<0.05)$ : Variety $=66.88$, Plant density $=79.54$, Interaction $=39.78$

\section{Discussion}

\subsection{Growth Parameters}

The tallest plant produced by SAMNUT 26, which was significantly higher than the rest of the groundnut varieties investigated was due to the genetic makeup of the variety and its growing environment as described by Bhagavatta, (2014). The tallest plants observed at 160,000 plants/ha might be due to mutual shading of the plants with increased competition for light thereby forcing the plants to grow taller by increasing the inter nodal length in search of light. Similar results were also reported by Dapaah (2014). Mukhtar et al (2005) also confirmed that the taller plants observed at higher plant density is attributed to competition by crops to intercept radiation. In addition, plants at high density tend to increase stem growth at the expense of assimilate partitioning to reproductive tissue. The shortest plant height measured with plant density of 40,000 plants/ha might be due to wide spacing arrangement which supported wider canopy sizes probably as a result of more available space for horizontal growth compared to the space available to closely spaced crop. However, close spacing resulted in complete and early canopy closure and this is consistent with the findings of Brown et al., (2005) and Tillman et al., (2006). The interaction effect of variety and plant 
density on plant height may be due to the genetic difference among the varieties and increased resource utilization efficiency in higher plant population densities. Mulatu et al, (2017) reported varying growth patterns in some groundnut genotypes which could be due to differences in their genetic makeup.

The varietal difference with reference to number of leaves per plant could be attributed to the genetic makeup and the habit of the varieties. Higher leaf number produced by the lower plant population density regardless of the varietal difference might be due to less competition for growth resources. The result was in line with that of Mulatu et al. (2017) who reported that groundnut produced greater number of leaves at the lowest plant density while the lowest number of leaves was recorded from the highest plant density. The high number of branches obtained in SAMNUT 26 may also be attributed to the genetic makeup of the variety and its environment. The effect of the high plant density resulted in significantly lesser number of branches than those in the low plant density. This was probably as a result of early competition and lack of elaborate space between closely spaced seedlings for light which encouraged vertical growth. Close spacing significantly reduced number of branches as plants were compelled to grow vertically to compete for space and light (Farnham, 2001). Low plant density supported higher number of branches probably as a result of more available space for horizontal growth compared to the space available to high plant density crops. However, high plant density resulted in complete and early canopy closure. This is consistent with the findings of Tillman et al. (2006) and Konlan et al. (2013). According to Dapaah et al (2014), wider spacing or lower plant density supported more branches per plant probably because of more available space for horizontal or lateral growth compared to close spaced or higher plant density crops. Closer spacing or higher plant density reduced branching as plants competing for space and light were compelled to grow taller. Gulluoglu et al (2016b) also recorded that, at low plant density, existing plants developed more branches and pegs because of reduced competition.

The increase in plant shoot dry weight from 8-12 was consistent with the growth pattern of groundnut. The differences in shoot dry weight observed could be attributed to varietal factors that led to some varieties achieving higher rates of photosynthesis, thereby accumulating more dry matter under the same conditions, supporting earlier findings of Kolan et al, (2013). Low plant density resulted in higher plant shoot dry weight probably because of lesser competition for growth resources compared to higher densities. The poor performance of the high density plants can be attributed to early competition and subsequent depletion of growth resources by the high density crop, coupled with the effects of mutual shading which reduced photosynthetic rates, resulting in lower shoot dry weight. Similar results have been reported by Meena et al., (2011), Kolan et al., (2013).

Number of days to 50 per cent flowering was not found significant among varieties and interaction irrespective of the plant densities tried. Plants in the higher densities flowered earlier as a result of the competition offered by higher plant population. Delayed flowering observed with lower plant densities was mainly due to elimination of inter or intra plant competition for growth resources which leads to increased vegetative growth and continuous flowering. The results are in conformity with Soumya et al. (2011). 
Leaf area index also followed the same trend of increasing with increase in plant density. The highest leaf area index obtained with the plant density of 160,000 plants/ha was due to more number of plants unit area ${ }^{-1}$ while the lowest leaf area index at the plant density of 40,000 plants/ha was due to lesser number of plants unit area ${ }^{-1}$ and space occupied by the plant. The present results are in conformity with the findings of Rama Jyothi et al. (2004), Hirwe et al. (2006) and Bhagavatta, (2014). The highest leaf area index computed with SAMNUT 26 might be due to its more number of leaves with bigger size while the lowest leaf area index produced by SAMNUT 25 might be due to compact growth habit of SAMNUT 25. However, increasing plant density tended to increase crop growth rate per plant, Relative growth rate per plant and Net assimilation rate. The increased Crop growth rate with respect to increased plant density is in conformity with the findings of (Rama Jyothi et al., 2004) and (Haricharan et al., 2014).

\subsection{Yield and Yield Components}

The differences in number of pods among the varieties could be attributed to genotypic differences and their response to adverse environmental effects. SAMNUT 26 and 25 could be said to be higher yielding in the number of pods per plant than SAMNUT 24. The lower number of pods per plant produced by the high plant density may be attributed to increased intra-specific competition for growth resources and decreased number of pegs compared to the low sowing densities. Increases in pods per plant with reduced plant densities have also been reported by Meena et al (2011), Soumya et al ((2011), Pratap et al (2013) and Dapaah et al (2014). Closer spacing of $30 \mathrm{x} 10 \mathrm{~cm}$ recorded significantly higher pod yield (Chandrasekaran et al., 2007).

Varietal difference with reference to pod weight and 100 seed weight could also be attributed to the genetic makeup of the groundnut varieties. SAMNUT 24 which is a small seeded variety weighed lesser than SAMNUT 25 and 26. Plant density differences regarding Pod weight and 100 seed weight might be due to the competition for light, water and other essential requirements among the plants. Ahmad et al. (2007) and Konlan et al. (2013) reported that 100 seed weight decreased with increasing plant density in peanut. These findings are supported by Gulluoglu et al (2016b) who indicated that decreasing plant density provides higher photosynthesis per plant. Increased competition for growth resources unit area ${ }^{-1}$ at higher plant population was the major reason for decreased pod weight due to poor translocation of photosynthates from vegetative parts to pods at the time of maturity. Similar results of increased pod weight with lower plant population compared to higher plant population was also reported by Dhawale et al. (2003) Rama Jyothi et al (2004), and Awal and Aktar (2015).

The varietal difference with regards to number of seeds per pod might be attributed to plant genetic factors than agronomic practices. The decreased number of seed per pod associated with increased plant density could be as a result of competition which occurred in the highly populated plants that led to vertical growth of the plants with lesser branches and number of matured pods. Similar results were reported by Mulatu et al (2017). The interaction effect on number of seeds per plant indicates the genetic control of the trait as well as it being subject to environmental influence. This supports the findings of Kolan et al, (2013).

Shelling percentage of groundnut was significantly influenced by varieties and plant 
populations. The highest shelling percentage produced by SAMNUT 24 might be due to better channelization of more photosynthates from vegetative parts to developing seeds and thinner pod wall which might have encircled the seed more tightly. Likewise, Bhagavatta, (2014) reported that the shelling percentage computed with Dharani was significantly higher than the rest of the varieties and might be due to better channelization of more photosynthates from vegetative parts to developing kernels resulting in complete filling of the pods. According to him, the shelling percentage depends upon the thickness of the pod wall, development of the kernel and flowering pattern during crop period. The shelling percentage was reduced with increased plant population due to severe competition for growth resources and poor translocation of photosynthates from pod walls and other vegetative plant parts to developing pods. Hirwe et al. (2006) also reported that the shelling percentage was decreased with increasing plant population from 0.4 to 9.34 lakh ha $^{-1}$. The lowest shelling percentage calculated with plant population of $160,000 \mathrm{Kg} \mathrm{ha}^{-1}$ might be due to poor source-sink relations at higher plant populations.

Variations in total yield of groundnut were probably attributable to genetic differences between varieties and how they responded to environmental changes. Similar findings have been reported by earlier studies (Shambhakar et al., 2006; Abdullah et al., 2007; Virender and Kandhola, 2007 and Kolan et al., 2013). The highest total yield of groundnut obtained with SAMNUT 26 might be due to the partitioning ability of photosynthates from growth parameters. (Labana et al. 1980) reported that the pod yield of groundnut mainly depends on partitioning ability of photosynthates from growth parameters viz., plant height, LAI and Dry Matter Production (DMP) to developing pods for producing more number of filled pods plant $^{-1}$ and hundred kernel weight which in turn led to increased total yield. All these yield promoting characters were significantly higher with SAMNUT 26 due to better partitioning of photosynthates to developing pods. The higher total yield which was resulted in high plant density might be due to efficient utilization of space and other growth resources, which in turn created favourable environment for producing optimum stature of growth parameters like plant height, LAI and DMP coupled with better partitioning of phototsynthates to developing pods and finally produced the higher number of matured pods unit area ${ }^{-1}$, Bhagavatta, (2014). This finding is in agreement with (Virk et al., 2005) who reported that the spacing arrangement that resulted in high plant population density was more efficient in the use of solar energy and other resources for pod production.

\section{Conclusion}

Based on the findings of this research work, it can be concluded that variety and plant density in a given area greatly determines growth and development of crops particularly the yield components. Optimizing plant population density is very critical in increasing production and productivity of a crop in a given area. The results from the study indicated that variety and plant density had a significant influence on the growth, yield components and yield of groundnut. SAMNUT 26 with the total yield of $\left(5294.25 \mathrm{~kg} \mathrm{ha}^{-1}\right)$ was found to produce the highest yield in the study area while the total yield $\left(6775.17 \mathrm{~kg} \mathrm{ha}^{-1}\right)$ obtained from the highest density (160,000 plants/ha) was the highest. Also, this density achieved rapid canopy closure with a potential to smother weeds and prevent subsequent germination of weed seeds. 


\section{References}

Abdullah, T., Rahmianna A. A., Hardaningsih, S., \& Rozi, F. (2007). Increasing groundnut yield on dry land Alfisols in Indonesia. J. SAT Agric. Res., 5(1).

Adu-Dapaah, H. K., Asibuo, J. Y., Danquah, O. A., Asumadu, H., Haleegoah, J., \& Asafu-Adjei, B. (2004). Farmer participation in groundnut rosette resistant varietal selection in Ghana. In: Proceedings of the 4th International Crop Science Conference, IJPSS, Article no. IJPSS.2014.9.004 1081

Ahmad, N., Mohammad, R., \& Ulas, K. (2007). Evaluation of different varieties, seed rates and row spacing of groundnut, planted under agro-ecological conditions of Malakand Division. Journal of Interacademia, 9(4), 178-183.

Ajeigbe, H. A., Waliyar, F., Echekwu, C. A., Ayuba, K., Motagi, B. N., Eniayeju, D., \& Inuwa, A. (2014). A Farmer's Guide to Groundnut Production in Nigeria. Patancheru 502 324, Telangana, India: International Crops Research Institute for the Semi-Arid Tropics. 36 pp.

Amato, G., Cibella, R., Giambalvo, D., \& Gristina, L. (1992). Observations of the reproductive development in faba bean (Vicia faba L. var. equina) in relation to plant density pp. 245- 246. In: Proceedings of the 1st European Conference on Grain Legumes, Angers, France.

Awal, M. A., \& Aktar, L. (2015). Effect of Row Spacing on the Growth and Yield of Peanut (Arachis hypogaea L.) Stands. International Journal of Agriculture, Forestry and Fisheries, 3(1), 7-11.

Bhagavatta, T. P. (2014). Performance of groundnut varieties under different plant populations during early kharif. J.Agric.Sc., 5, 103-109.

Brown, S. L., Culbreath, A. K., Todd, J. W., Gorbet, D. W., Baldwin, J. A., Coolman, R. M., \& Hoyt, G. D. (2005). Increasing sustainability by intercropping. Hor. Technol., 3(3), 309-311. https://doi.org/10.21273/HORTTECH.3.3.309

Chandrasekaran, R., Somasundaram, E., Mohamed Amanullah, M., Thirukaran, K., \& Sathyamoorthi, K. (2007). Influence of varieties and plant spacing on the growth and yield of confectionary groundnut (Arachis hypogaea L.). Research Journal of Agriculture and Biological Sciences, 3(5), 525-528.

Dalley, C. B., Kells, J. J., \& Renner, K. A. (2004). Effect of glyphosate application timing and row spacing on weed growth in corn (Zea mays) and soybean (Glycine max). Weed Techno, 18, 177-182. https://doi.org/10.1614/02-150B

Dapaah, H. K., Ibrahim, M., \& Richard, T. A. (2014). Growth and Yield Performance of Groundnuts (Arachis hypogaea L.) in Response to Plant Density. International Journal of Agricultural Research, 9, 87-98. https://doi.org/10.9734/IJPSS/2014/9445

Dhawale, M. B., Shinde, S. H., \& Charjan, Y. D. (2003). Effect of plant density and fertilizer levels on summer groundnut in sorghum- groundnut system. Journal of Maharashtra Agricultural Universities, 28(2), 180-181. 
EBADEP (2005). Weather data. Ebonyi State Agricultural Development Program

FAO (2010). Crop production statistics. Food and Agriculture Organization of United Nations, Rome, Italy. Crop Sci., 42, 146-151.

Farnham, D. E. (2001). Row spacing, plant density, and hybrid effects on corn grain yield and moisture. Agron. J., 93, 1049-1053. https://doi.org/10.2134/agronj2001.9351049x

Gulluoglu, L., Bakal, H., Onat, B., Kurt, C., \& Arioglu, H. (2016b). The Effect of Harvesting Dates on Yield and Some Agronomic and Quality Characteristics of Peanut Grown in Mediterranean Region (Turkey) Turk J Field Crops, 21(2), 224-232. https://doi.org/10.17557/tjfc.20186

Haricharan, R. K., Arun, K. J. S., \& Ghosh, G. (2014). Effect of plant spacing on the yield and yield attributes of groundnut varieties. Internat. J. agric. Sci., 10(1), 79-81.

Hirwe, N. A., Ulemale, R. B., Paslawar, A. N., Thakur, M. R., \& Anokar, D. N. (2006). Productivity and economics of groundnut influenced by plant density under polythene film mulch. Annuals of Plant Physiology, 20(1), 148-149.

Janila, P., \& Mula, M. G. (2015). Cultural Management Practices of Groundnut. J. Agric. Sc., 147, 171-191.

Konlan, S., Sarkodie-addo, J., Asare, E., \& Kombiok, M. J. (2013). Groundnut (Arachis hypogaea L.) Varietal Response to Spacing in the Guinea Savanna Agro-Ecological Zone of Ghana. Growth and Yield. African J. of Agriculture Research, 8(22), 2769-2777.

Labana, K. S., Singh, M., Sangha, A. S., \& Jaswal, S. V. (1980). Variability and inter-relations among characters in F2 progeny of groundnut. Journal of Research, Punjab Agricultural University, 17(2), 107-114.

Lanier, J. E., Jordan, D. L., Spears, J. F., Wells, R., Johnson, P. D., Barnes, J. S., \& Bailey, J. E. (2004). Peanut Response to Planting, Row Spacing, and Irrigation. Agronomy Journal, 96, 1066-1072. https://doi.org/10.2134/agronj2004.1066

Meena, B. P., Kumawat, S. M., \& Yadav, R. S. (2011). Effect of planting geometry and nitrogen management on groundnut (Arachis hypogaea L.) in loamy sand soil of Rajasthan. Indian Journal of Agricultural Sciences, 81(1), 86-88.

Mlingom, J. K., \& Craufurd, P. Q. (2007). Productivity and optimum plant density of pigeon pea in different environment in Tanzania. J. Agric. Sci., Cambridge, 145, 343-351. https://doi.org/10.1017/S0021859607006776

Mukhtar, A. A., Tanimu, B., Ibrahim, S., Mohammad, A. A., \& Jaliya, M. M. (2005). Growth and development of three groundnut (rachis hypogaeal.) varieties as affected by basin size and plant population at kadawa, Sudan Savanna Nigeria.

Mulatu, G., Tamado, T., \& Elias, U. (2017). Effect of planting density on yield components and yield of groundnut (Arachis hypogaea 1.) varieties at Abeya, Borena zone southern Ethiopia. International Journal of Scientific Engineering and Applied Science (IJSEAS), 3(3).

Naab, J. B., Boote, K. J., Prasad, P. V. V., Seini, S. S., \& Jones, J. W. (2009). Influence of 
fungicide and plant density on the growth and yield of two groundnut cultivars. J. Agric. Sci., 147, 179-191. https://doi.org/10.1017/S0021859608008290

Naab, J. B., Tsigbey, F. K., Prasad, P. V. V., Boote, K. J., Bailey, J. E., \& Bradenburg, R. L. (2005). Effects of sowing date and fungicide application on yield of early and late maturing peanut cultivars grown under rain fed conditions in Ghana. Crop Protec., 24, 325-332. https://doi.org/10.1016/j.cropro.2004.09.002

Obi, I. U. (1986). Statistical methods of detecting differences between treatment means, SNAAP Press, Enugu, Nigeria, VI + 45 pp.

Pratap, B., Srinivas, R. D., Rama, R. G., Subramanyam, D., \& Muneendra, N. S. M. (2013). Growth and yield of export oriented groundnut as influenced by different planting pattern, nitrogen and weed management practices. The Andhra Agriculture Journal, 60(2), 269-274.

Rama, J. M., Radha, K. C., Obulamma, U., \& Lingam, B. (2004). Response of early Rabi groundnut, Arachis hypogeal L. to spacing, irrigation and plant protection levels. Journal of Oilseeds Research, 21(1), 171-172.

Shambhakar, D. A., Dharne, P. K., Bahale, T. M., Anjali, D., Surywanshi, R. T., \& Jadhav, R. B. (2006). Assessment of Integrated Pest Management Modules in Groundnut on Farmers Fields. International Arachis Newsletter, 26, 31-33.

Soumya, B., Suneetha, D., K. B., Siva, L. Y., \& Uma, M. K. (2011). Studies on seed rate for promising groundnut varieties under rain fed conditions of Southern Telangana zone, Andhra Pradesh. Journal of Research ANGRAU, 39(4), 76-78.

Steel, R. G. D., \& Torrie, J. H. (1980). Principles and Procedures of Statistics. (2nd ed.). New York: McGraw-Hill

Tillman, B. L., Gorbert, D. W., Culbreath, A. K., \& Todd, J. W. (2006). Response of peanut cultivars to seeding density and row patterns. Online Crop Management. https://doi.org/10.1094/CM-2006-0711-01-RS

Virender, S., \& Kandhola, S. S. (2007). Productivity of semi-spreading and bunch type varieties of groundnut as influenced by sowing dates. J. SAT Agric. Res., 5(1).

Virk, A. S., Kaul, J. N., Bhangoo, B. S., \& Singh, A. (2005). Influence of planting techniques and plant population on Biology and pod productivity of summer groundnut varieties. Res. Crops, 6(1), 173-174.

\section{Copyright Disclaimer}

Copyright for this article is retained by the author(s), with first publication rights granted to the journal.

This is an open-access article distributed under the terms and conditions of the Creative Commons Attribution license (http://creativecommons.org/licenses/by/4.0/). 